\title{
Health in the rural environment: a postural evaluation of milking workers in Brazil
}

\author{
Claudilaine Caldas de Oliveira ${ }^{1, *}$, Antônio Augusto de Paula Xavier ${ }^{2}$, Leandra Ulbricht ${ }^{2}$, \\ Antônio Renato Pereira Moro ${ }^{1}$ and Marjorie Maria Belinelli ${ }^{2}$ \\ ${ }^{1}$ Federal University of Santa Catarina (UFSC), Florianópolis, Brazil \\ ${ }^{2}$ Federal Technological University of Paraná (UTFPR), Curitiba, Brazil
}

\begin{abstract}
This study aims to evaluate the postures of workers during the activities of milking and handling dairy cattle in the Community of Campo Mourão Municipalities, in Brazil. To identify the presence of musculoskeletal symptoms, the study was divided into two stages: first, we identified the demographic profile of the sample through a questionnaire and then obtained information about problems with pain and discomfort by applying the Standardised Nordic Questionnaire. The second stage consisted of an analysis of the activity of six farms to identify the natural ergonomic risk factors. To evaluate and record the postures, we used the REBA method (Rapid Entire Body Assessment) to correlate the prevalence of pain/discomfort with the positions adopted by workers in a production system. The study demonstrated that $87 \%$ of workers had pains and showed that the main postures throughout the workday are trunk tilting and bending, characterizing a job that requires awkward postures, with a high level of effort, in most activities, which may contribute to the development of musculoskeletal injuries for these workers. The REBA method also pointed out a high level of risk. During their routine, dairy farm workers adopt harmful positions that cause a high prevalence of pain/discomfort. Ergonomic recommendations are thus proposed to reduce these awkward postures of workers and consequently improve their quality of life at work.
\end{abstract}

Keywords: production system / milking / uncomfortable postures / REBA-method /

Résumé - La santé en milieu rural : une évaluation des postures des travailleurs laitiers au Brésil. Cette étude vise à évaluer les postures des travailleurs qui font la traite et s'occupent des vaches laitières dans la Commune de Campo Mourão, au Brésil. Afin d'identifier la présence de symptômes musculosquelettiques, l'étude a été menée en deux étapes. Tout d'abord, nous avons déterminé le profil démographique de l'échantillon d'individus à travers un questionnaire et nous avons collecté des informations sur les problèmes de santé courants comme la douleur ou l'inconfort, en appliquant le Standardised Nordic Questionnaire. Puis, dans une seconde étape, nous avons analysé l'activité de six exploitations pour identifier les facteurs de risque ergonomiques naturels. Nous avons choisi la méthode REBA (Rapid Entire Body Assessment) pour évaluer et enregistrer les postures et établir une corrélation entre la prévalence de la douleur ou de l'inconfort et les postures prises par les travailleurs dans les systèmes de production. L'étude a montré que $87 \%$ des travailleurs ressentaient des douleurs lombaires et que les principaux mouvements tout au long de la journée de travail étaient l'inclinaison et la flexion de la colonne vertébrale, avec un travail qui exige des positions inconfortables et un haut niveau d'effort dans la plupart des activités, ce qui peut contribuer au développement de lésions musculo-squelettiques chez les ouvriers. La méthode REBA a également souligné un haut niveau de risque pour la santé. Au cours de leurs tâches quotidiennes, les travailleurs laitiers adoptent de mauvaises positions qui causent une prévalence élevée de douleur ou d'inconfort. Des recommandations ergonomiques sont proposées pour réduire ces mauvaises postures et ainsi améliorer la qualité de vie au travail.

Mots clés : système de production / traite / postures inconfortables / méthode REBA

\footnotetext{
* Corresponding author: claudilainecaldas@gmail.com.
} 


\section{Introduction}

Work in rural areas is considered inherently risky for both climatic and/or economic reasons. Risks posed to the health and safety of rural workers in Brazil are increasing, due to the inadequacy of organization (Hostiou et al., 2015).

Several researchers have identified a high prevalence of musculoskeletal symptoms (MSS) among dairy farm workers (Stål et al., 2003a; Perkiö-Mäkelä and Hentilä, 2005; Jakob et al., 2012; Douphrate et al., 2016). Many musculoskeletal disorders have been reported in dairy farm workers due to activities that involve high risk factors in terms of heavy-load lifting and carrying, repetitive movement and awkward postures (Perkiö-Mäkelä and Hentilä, 2005; Kolstrup and Hultgren, 2011). Musculoskeletal disorders are common among farmers, and particularly their back problems are associated with manual handling of materials and forwardbending work postures, as in milking. In dairy farming, in particular, workers can be exposed to ergonomic risks during the milking activity and accidents, especially when handling animals (Pinzke, 2003). Musculoskeletal disorders among dairy farm workers are generally associated with the shoulder, elbow, lower back, hip and knee (Pinzke, 2003; Lundqvist et al., 1997).

Therefore, it is important to investigate whether the new milking methods have changed the high physical workload required in this activity (Ahonen et al., 1990; Németh et al., 1990).

Little information is available about the prevalence of risk factors for the onset of skeletal muscle diseases among dairy farm workers in Brazil. Recent investigations have been undertaken to evaluate the prevalent disorders of the musculoskeletal system, and exposure to risk factors for MSS among dairy farm workers is one of the health-related concerns that have attracted the attention of researchers (Oliveira et al., 2017; Ulbricht et al., 2014; Maia and Rodrigues, 2012).

In general, rural workers are directly responsible for their work activities such as milking and handling dairy cattle, which expose them to risks, especially ergonomic hazards and accidents.

Because of the presence of risk factors for the onset of skeletal muscle diseases in dairy farming, an ergonomic evaluation of the attitude of the workers in relation to dairy milking activities in rural properties was considered necessary. The present study was carried out in the Community of Campo Mourão Municipalities (COMCAM), in Brazil. The region was chosen because of the significant presence of family farms that consider milk as an important economic activity.

\section{Method}

The proposed methodology is characterized as a thorough quali-quantitative, explorative study of multiple cases.

The research was developed in two phases. In the first phase, the main objective was to characterize dairy farm activities, the workers and the milking system, to obtain complaints and symptoms indicative and/or showing prevalence of Work-related musculoskeletal disorders (WMSDs) among the workers. In the second phase, based on machineassisted observations, an activity analysis was performed to seek and identify risks of an ergonomic nature present in the milking activity to extrapolate these results to other milking activities in the COMCAM region.

The first phase of the research involved 163 farm workers from 156 dairy farms located in the state of Paraná, Brazil. The work is operated by the dairy farm owners themselves and their family, including their children (mostly kids), and occasionally some seasonal employees. The 163 farmers and dairy farm workers then responded to the General and Occupation Data Questionnaire and Standardised Nordic Questionnaire (Kuorinka et al., 1987).

The General and Occupation Data Questionnaire was used to collect information about the participants such as age, gender, height, weight, education, employment, age at starting work with milking, working time as a milker, job satisfaction, dairy farm activities, occasions taking over the dairy farm, number of parlor workers (milkers), number of milking per day, hours per day performing dairy operation activities, number of cows milked, number of years spent working with dairy cows, working with other activities and description and characteristics of the milking system (milking type, number of the milking cluster, milking parlor design).

The Standardised Nordic Questionnaire was used to evaluate the musculoskeletal symptoms and obtain information about pain and or discomfort occurring in the periods of 12 months and seven days prior to the application of the questionnaire. The Standardised Nordic Questionnaire includes a picture of the human body with 27 anatomical regions to analyze perceived symptoms of musculoskeletal pain and disorders in the different parts of the body. The following question was asked to the participants: "during the last 12 months, have you regularly experienced aches, pains and discomfort in the neck, shoulders, elbows, hands/wrists, upper back, lower back, hips, knees, or feet?" The respondents could answer "Yes" or "No" to each part of this question. The questionnaire was also designed to obtain information concerning perceived Musculoskeletal symptoms (MSS) seven days prior to the study, and whether or not the subjects had been prevented from working. Perceived MSS "in any body part" was added to describe if the participants had experienced musculoskeletal symptoms in at least one of the different body parts.

Six dairy farms agreed to participate in the second phase of the research. In the six participating dairy farms, nine farmers and farm workers (seven males and two females), aged 34 49 years, were taking part daily in the milking activity. The mean weight and height of the subjects were $80 \mathrm{~kg}$ (range of 66 to $98 \mathrm{~kg}$ ) and $173 \mathrm{~cm}$ (range of 165 to $180 \mathrm{~cm}$ ).

For the records and evaluation of the overall posture at work, we used the REBA (Rapid Entire Body Assessment) method proposed by Hignett and McAtamney (2000). This method allows for a combined analysis of the postures shown by the workers during the activity, dividing the postures and biomechanical risk factors by groups:

- group A (neck, trunk and legs);

- group B (load/force);

- group C (arm, forearm and wrist);

- group D (quality of handling);

- group E (frequency of the activity). 
In this way, the results of the method provide a final assessment of the posture, classifying it by scores (from 11 or higher) that indicate the risk levels and the required intervention, as follows:

- 1: insignificant risk (no intervention necessary);

- 2 or 3: low risk (intervention may be necessary);

-4 to 7: medium risk (intervention necessary);

-8 to 10: high risk (intervention necessary as soon as possible);

- 11 or more: very high risk (immediate intervention necessary).

Pearson's Chi-square test $\left(\chi^{2}\right)$ and Fisher's Exact test were applied to determine the existence of associations in relation to the frequencies of pain or lack thereof with the sex variables of the milkers and the type of production system, using the Minitab $15^{\circledR}$ software. Associations were considered significant when $p \leq 0.05$.

This research was submitted to and approved by the Committee of Ethics in Research Involving Human Beings (CAEE), under no. 21513713.5.0000.0121.

\section{Results}

\subsection{Sample profile}

Among the interviewed people (163 parlor workers, i.e., milkers), 43 are female $(26.4 \%)$ and 120 are male $(73.6 \%)$. The average age of the sample is 43.4 years; the youngest participant being 13 years old and the oldest, 81 years old. The education level of most interviewed people is low. No worker has completed higher-level education and only $20.2 \%$ have completed high school. Regarding their employment relationship, the majority $(107 ; 65.6 \%)$ are farm owners.

\subsection{Milking activity}

\subsubsection{Time of activities and load of work}

The workers have been in this occupation for 20 years, on average (median 17 years). The minimum working time is five months and the maximum is 70 years.

Most of them work about $11 \mathrm{~h}$ per day; the milking activity, a subtask of the whole milk extraction process, takes $3 \mathrm{~h}$, on average. Four hours are spent on activities involving the handling of dairy cattle (planting, harvesting, feeding, vaccination, insemination, etc.) and the remaining time is spent on other activities. The full amount of work per week, including all activities on the property, was $77.1 \mathrm{~h}$.

Among the 163 milkers interviewed, 61.3\% (100 milkers) only performed the dairy cattle activity and 38.6\% (63) performed other activities such as agriculture and beef cattle rearing. On average, 17 animals are milked in each milking session, with a minimum of three animals milked and a maximum of 100 . Most workers $(71.2 \%$; 116) milked cows twice daily, and $28.8 \%$ (47) performed it once daily and adopted a manual milking system.

The milking activity is considered dull and inflexible with regard to working hours. The milkers wake up very early to do the milking, in addition to having a high daily workload (no weekends, days off, or holidays). These workers do not have leisure activities and are geared practically entirely towards working.

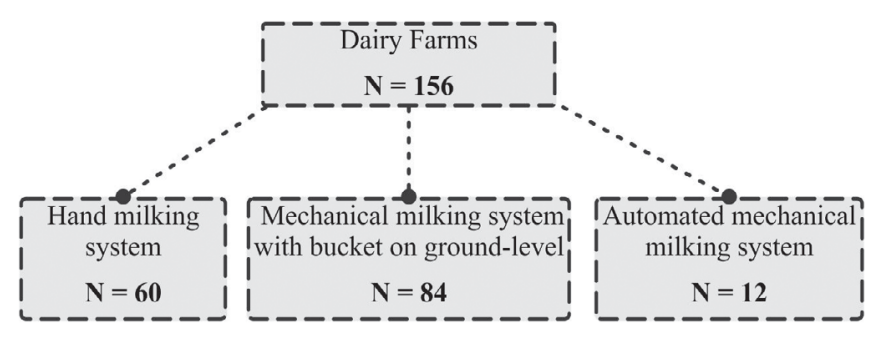

Fig. 1. Distribution of the milking systems in the surveyed dairy farms.

Fig. 1. Répartition des systèmes de traite dans les fermes laitières étudiées.

\subsubsection{Milking system}

Among the 156 visited dairy farms:

- 60 adopt manual milking;

- 84 perform it mechanically, with the bucket at floor level. Four of these farms have a milking parlor with differentiated height for the milking machine (operator pit);

- 12 dairy farms have the automated mechanical milking system connected to milk ducts. Four of these dairy farms have a milking parlor with differentiated height for the milking machine (operator pit); herringbone and parallel parlor types are used (Fig. 1).

However, most adopt a mechanical milking production system with bucket at the foot $(53.8 \%)$; the second most widely adopted type is manual milking (38.5\%). In the research area, the majority of farms with dairy activity are family farms and are little specialized in this field.

\subsection{Dairy farms' milking system description and characteristics}

The milking system of the six dairy farms participating in the second phase of the study includes the following activities after the milker has gathered the cows together:

- tying the legs and tail of the cows;

- dispensing the first jet of milk;

- cleaning the cow's udder;

- taking test sprays of milk;

- pre-dipping;

- attaching the milking cluster to the cow's udder;

- observing the milk flow;

- creaming the cow's udder;

- disconnecting the milking cluster;

- post-dipping;

- feeding the calves;

- feeding heifers and cows;

- washing the milking cluster and the parlor.

The six dairy farms in the study and milking system characteristics are described in Table 1. On dairy farms 3, 4 and 5, the workers operate in a pit below the level of the dairy cows. Farms 1, 2 and 6 have a milking parlor with differentiated height for the milking machine (operator pit). 
Table 1. Description of the six dairy farms in the study. Tableau . Description des six fermes laitières étudiées.

\begin{tabular}{llllll}
\hline Dairy farm & Classification of milking parlor operations & $\begin{array}{l}\text { Milking parlor } \\
\text { configuration } \\
\text { (design) }\end{array}$ & $\begin{array}{l}\text { Number of } \\
\text { cows milked }\end{array}$ & $\begin{array}{l}\text { Number of } \\
\text { milking units }\end{array}$ & $\begin{array}{l}\text { Number of } \\
\text { milkers }\end{array}$ \\
\hline 1 & No stanchion (manual) system and no & - & 50 & 1 & 2 males \\
2 & stanchion (tethering) system & - & 12 & - & 1 male \\
3 & No stanchion (manual) system & Parallel & 10 & 1 male and 1 female \\
4 & Stanchion (tethering) system & Parallel & 10 & 2 & 1 male \\
5 & Stanchion (tethering) system & Herringbone & 32 & - & 1 male and 1 female \\
6 & Stanchion (tethering) system & - & 20 & & 1 male \\
\hline
\end{tabular}

\subsection{Problems (pain and/or discomfort) in the musculoskeletal system}

Addressing pain and/or discomfort in the musculoskeletal system, 87\% (142) of workers report complaints, with the highest prevalence of $74 \%$ in the lumbar region, $44.4 \%$ in the shoulder region, radiating to the upper limbs (arms, forearms and wrist), 22.2\% in the neck and lower extremities (hips, knees and legs), and $11.1 \%$ in the thoracic region. The applied questionnaires reveal varied pain conditions in both acute and chronic form. Eighty-six $(60.6 \%)$ workers have symptoms with multifocal appearance in the segments of the cervical vertebrae (neck) radiating to the upper limbs and shoulders, shoulders and arms, arms and wrists/hands.

Separating the sample by gender (Fig. 2), among the 43 interviewed female milkers, 37 have pain and discomfort $(86 \%)$, while 105 of the 120 males report pain and/or discomfort (87.5\%). Data show (Fig. 2) a slight difference in the percentage of complaints of pain between the sexes, with a higher prevalence of pain in males compared with females. The relationship between occurrence of pain and the sex of the milkers in the distribution of the chi-square test $\left(\chi^{2}\right)$ reveals that the values are independent; it is thus not possible to affirm that there is a relationship between sex and the occurrence of pain, since the calculated value is lower than the tabulated result $\left(\chi_{\text {calculated }}^{2}=0.060 ; \chi_{\text {tabulated }}^{2}=3.841\right)$.

With respect to the production system, the manual and mechanical milking systems were compared for all types of pain. As shown in Figure 3, manual milking is more harmful, with a prevalence of $95.3 \%$ of pain versus $82.6 \%$ reported for the mechanical milking system. This association is confirmed statistically, since the calculated chi-square test $\left(\chi^{2}\right)$ result is superior to its tabulated version $\left(\chi^{2}\right) \quad\left(\chi_{\text {calculated }}^{2}=4.362\right.$; $\left.\chi_{\text {tabulated }}^{2}=3.841\right)$, showing that the variables are dependent (significant). Thus, there is a relationship between the production system (manual and mechanic) and the occurrence of pain.

It is possible to identify that, in general, the work environment in the dairy industry has some risk factors to the workers. Associating these risks with the type of milk production system (milking), shows that in both the manual milking and mechanical systems, complaints of pain and discomfort by workers are present, with $60.6 \%$ of them reporting pain in different body segments at the same time.

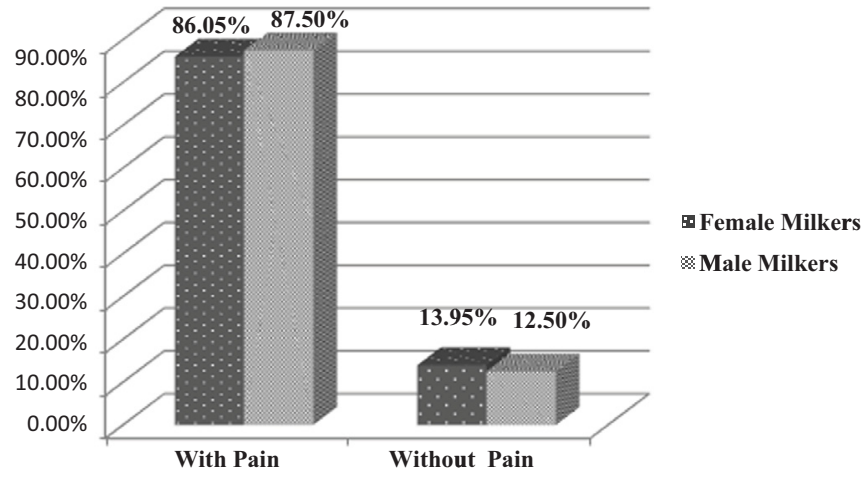

Fig. 2. Frequency distribution of pain and/or discomfort according to gender.

Fig. 2. Fréquence de la douleur et/ou l'inconfort selon le sexe.

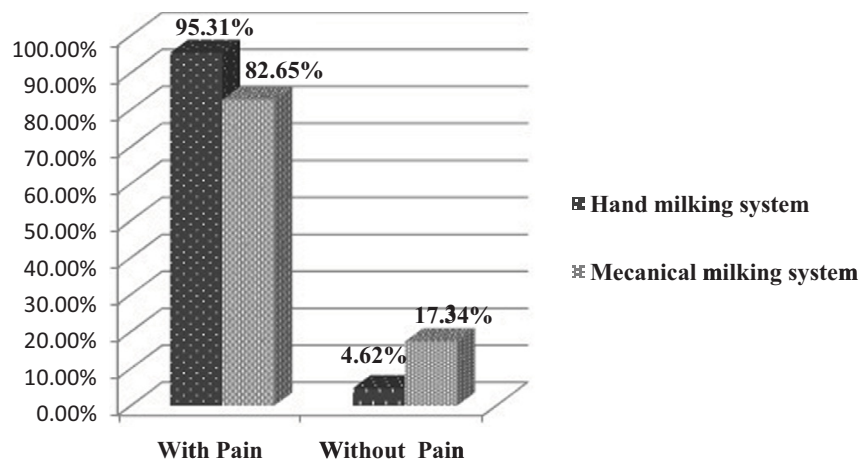

Fig. 3. Relationship between milking system and pain.

Fig. 3. Relation entre le système de traite et la douleur.

Considering the postures performed in the milking systems, manual milking requires strength of the hands, wrists and arms with repetitive movements as well as squatting posture (squatting) and several lateral deviation (torsion/ flexion) of the spine such as the cervical region so that the milker can view the animal's udder.

Thus, in the confrontation between the five production systems observed in the COMCAM region (Fig. 1), mechanical milking with the bucket at the foot (pit) is not a protection 

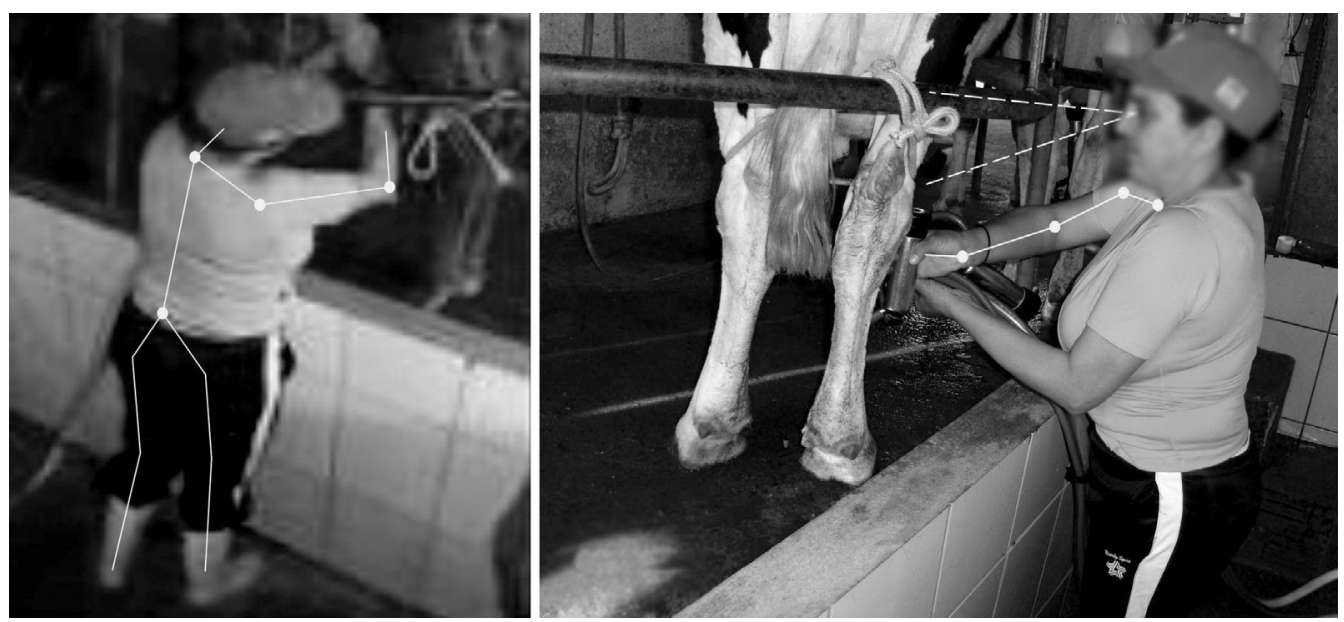

Fig. 4. Postures adopted for milking.

Fig. 4. Postures adoptées pour la traite.

factor as expected by the authors, because all milkers who work in this type of system also complain about pains. This situation is explained by the inadequacy of the pit to the anthropometric traits of the milkers (Fig. 4), especially in terms of floor height not being consistent with the milker's height. The placement of fixed protection bars to prevent the animals from falling into the pit is also a problem, as they are positioned at inappropriate heights, thereby interfering with the visual field, which leads to awkward postures (e.g. cervical deviation) that can cause or aggravate musculoskeletal disorders of the spine. In milking, during teat engagement, posture is static and the milker holds a weight of approximately $3.5 \mathrm{~kg}$ (weight of all the liners) with arms high above $90^{\circ}$. On the analyzed dairy farm, the parapet of the gap is higher than recommended. As presented in Figure 4, the milker posture shows arms elevated above $90^{\circ}$. Another situation that causes awkward postures involves the fixed protection bars in the "herringbone" type system, which are located approximately in the region of the eyes of the milkers, hindering visualization of the udder and forcing them to adopt a tilt and neck flexion and anterior flexion of the shoulder to see the animals' teats, $i$. e. their work field (Fig. 4).

In both manual milking system and mechanical bucket-atfoot system, buckets are handled during and after milking (lifting and loading), with approximately $60 \mathrm{~kg}$ of milk (Fig. 5). Loading these buckets requires muscular strength. Many workers use body parts like the upper limbs and shoulder as support, adopting the abduction position and raising the arms above $90^{\circ}$ to hold the bucket (Fig. $5 \mathrm{~b}, \mathrm{c}, \mathrm{g}$, h and i). Other postures are performed as the milkers walk with the load, and these positions lead to musculoskeletal problems and risks of accidents, e.g. the worker may fall on their way; additionally, there are steps, which represent obstacles on the ground (Fig. $5 \mathrm{~h}$ and i).

In the investigated production systems, the most frequent and similar postures are static postures of the upper limbs, loading weight, and squatting (which increases the load on the neck and lower back, hips, knees and feet/ankles), a predisposing factor for musculoskeletal pain and/or discomfort with the risk of causing diseases due to the additional burden to the joints and/or muscles but also to the spine.

\subsection{REBA method results}

We analyzed the main postures adopted by milkers in their different activities.

Seven activities are considered "high-risk" (final score of 8 to 10) and 13 were "very high-risk" (score of 11 or more). The task of "attaching the milking cluster to the cow's udder" is $50 \%$ high-risk for farms using milking with bucket at the foot of the milking parlor, where the employee works in the standing position. Mechanical production systems with bucket at the bottom are $50 \%$ very high-risk, for requiring a squatting posture.

The posture of greatest risk is the "anterior trunk flexion", considered an awkward position that can compromise the spine and that is often associated with load lifting. Thus, there is urgent need for changing the work posture.

\section{Discussion}

Results indicate that there is a high workload in milk production on dairy farms that may lead to prevalence of Work-related musculoskeletal disorders (WMSDs) among milkers. The average workload is $77.1 \mathrm{~h} /$ week, with no weekly rest allowances. Lack of rest compromises the recovery of the musculoskeletal system from the physical overloads and promotes increased physical and mental wear, leading to muscle pains reported by the workers.

In relation to pain and/or discomfort in the musculoskeletal system, $87 \%$ of milkers report complaints, with the highest prevalence of $74 \%$ in the lumbar region, $44.4 \%$ in the shoulder region, radiating to the upper limbs (arms, forearms and wrist), $22.2 \%$ in the neck and lower extremities (hips, knees and legs) and $11.1 \%$ in the thoracic region. These results are similar to those found in other studies conducted with this working class. Recent studies show that prevalence of Musculoskeletal symptoms (MSS) is frequently reported in "any body part" in Brazilian milkers $(78 \%)$, indicating that the most severely affected segment of the body is the lower back (62\%) (Oliveira et al., 2017). Swedish and German milkers ( $84 \%$ and $85 \%$, respectively) also complain of pain and discomfort, mainly in 

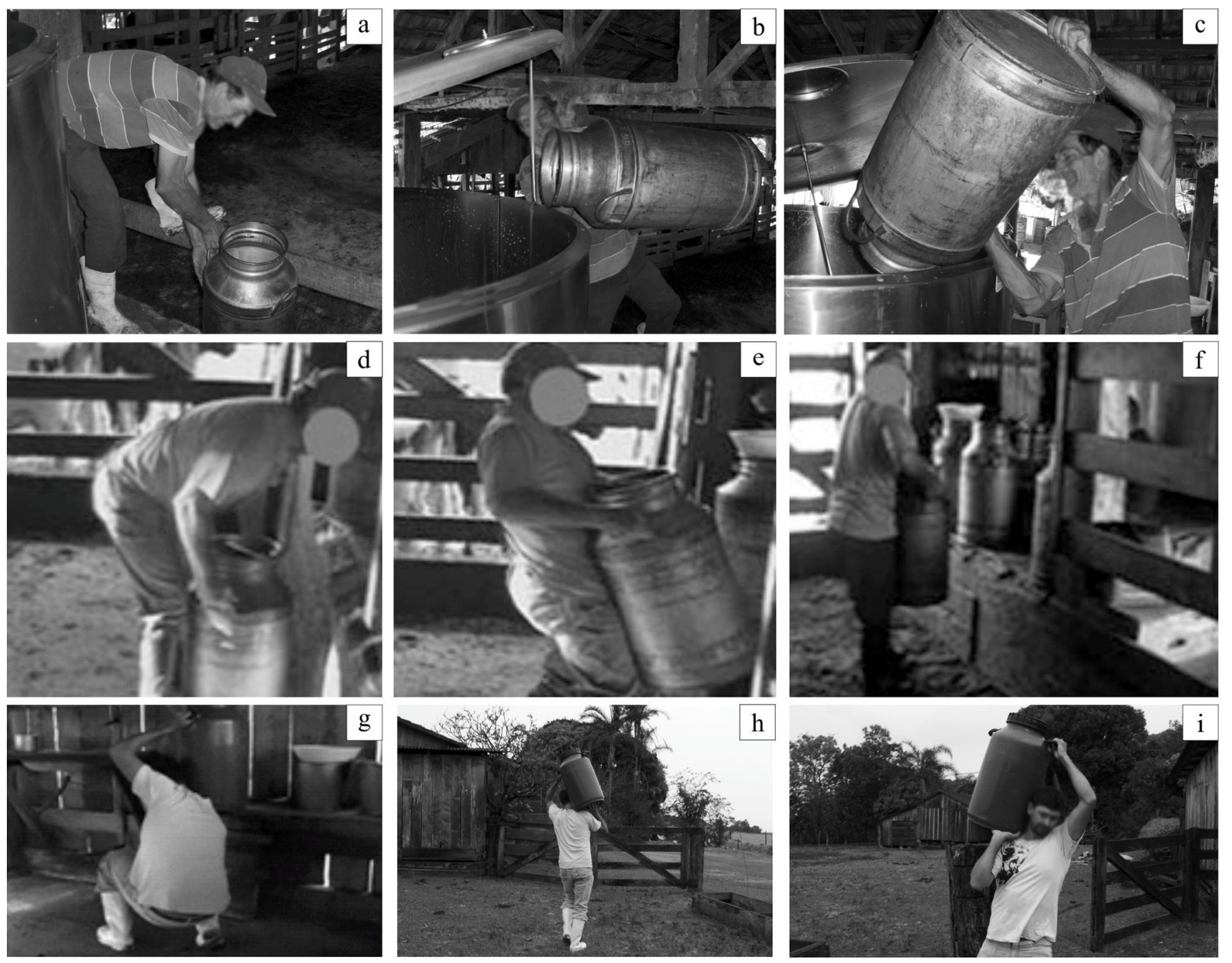

Fig. 5. Lifting of milk bucket from parlor to destination.

Fig. 5. Manipulation du bidon de lait de la salle de traite à la destination.

the lower back ( $49 \%$ and $61 \%$, respectively), shoulder $(47 \%$ and $52 \%$, respectively), neck ( $38 \%$ and $53 \%$, respectively) and hands/wrists (32\% and $42 \%$, respectively) (Kolstrup and Jakob, 2016).

Research conducted in the United States reveals the highest prevalence of MSS (over 60\%) in the upper extremity region followed by the lower extremity (near $60 \%$, on average), neck and upper back (around 50\%) and lower back (over 30\%) (Douphrate et al., 2016). As for the lower back, the results differ from those of the afore-mentioned studies. In this way, it appears that the problem is not restricted to the studied region, but is an issue pertaining to the entire dairy industry.

In their studies on the physical load during bucket manipulation, Milani and Souza (2010), Oliveira et al. (2013), Soares et al. (2013), Ulbricht et al. (2014), Hayati et al. (2015), and Cockburn et al. (2015) report that the squatting posture causes pain in the spine (chest and lumbar region) and in the knees.

In general, rural workers directly responsible for their work activity are exposed to ergonomic hazards and risks of accidents during their routine that can jeopardize their health and safety (Ulbricht et al., 2014; Oliveira et al., 2017). Studies led with Swedish milkers by Stål et al. (1996, 2003a, 2003b) reveal the presence of ergonomic hazards, mainly musculoskeletal disorders, caused by awkward postures and repetitive movements. These results concern both mechanical and manual milking, especially with respect to symptoms in the wrists and hands. Symptoms consist of pain, tingling sensation, numbness, and decreased muscle strength in addition to the complaints of pain in other body parts.

With respect to physical load, several studies in the USA and Europe show that even with high technology and a modern milking parlor, dairy farms still require physical loading and inadequate postures (Pinzke et al., 2001; Pinzke, 2003; Stål et al., 2003b, Jakob et al., 2012). Therefore, workers are prone to suffer pain and/or discomfort in the upper limbs (Douphrate et al., 2016; Kolstrup and Jakob, 2016).

Studied dairy workers are exposed to many risks, with ergonomic hazards and risk of accidents predominating. These findings are similar to those reported in the studies of Ulbricht 
et al. (2014) and Onofri and Michaloski (2015). It thus appears that the problem is not restricted to the researched site or the technologies employed, but is rather a part of the form of dairy production, both in small and large dairy farms.

\section{Recommendations}

Some ergonomic recommendations are proposed to minimize pain and/or discomfort and chronicity as well as to prevent diseases.

Regarding the production system, it is suggested that awkward postures and musculoskeletal overload could be avoided and that the mechanical production system with milk ducts in the milking parlor or milk protractors could be adopted with a different floor height between animals and milkers, but consistent with the stature of the worker. Therefore, protective bars should be mobile so that they can be adjusted to the height of the workers, thereby allowing adequate visualization of the udders and teats and reducing postures and movements that can cause or worsen impairments in the musculoskeletal system of the workers.

It was also observed that when working with the animals, the workers transport feed and silage manually; wheelbarrows could be adopted to assist in loading.

Regarding technologies, mechanical milking should be adopted with two sets of liners to prevent an overload of the milker's musculoskeletal system.

\section{Conclusion}

On all dairy farms, the diagnoses provided by ergonomic analysis and the REBA method indicate that jobs are generally inadequate, constantly demanding the squatting posture and several side deviations (torsion/flexion) of the spine - in many cases without proper health or safety conditions. These jobs require physical and repetitive strain that may cause disorders of the musculoskeletal system, particularly vertebral pains and Work-related musculoskeletal disorders (WMSD).

However, additional studies are needed to investigate this sector, involving other methods of analysis that could quantify this situation of heavy loads and elevated muscle activity faced by milkers, e.g. the use of surface electromyography (EMG). Moreover, new approaches must be developed to reduce the prevalence of work-related disorders, such as facilities ergonomically adapted to the milkers - especially the milking room and milking machine--, since these measures can reduce their exposure to work hazards and thus positively affect their health and productivity.

\section{References}

Ahonen E, Venäläinen M, Könönen U, Klen T. 1990. The physical strain of dairy farming. Ergonomics 33(12): 1549-1555.

Cockburn M, Savary P, Kauke M, Schick M, Hoehne-Hückstädt U, Hermanns I, et al. 2015. Improving ergonomics in milking parlors: empirical findings for optimal working heights in five milking parlor types. Journal of Dairy Science 98(2): 966-974. DOI: 10.3168/jds.2014-8535.

Douphrate D, Nonnenmann M, Hagevoort G, Gimeno D. 2016. Workrelated musculoskeletal symptoms and job factors among large- herd dairy milkers. Journal of Agromedicine 21(3): 224-233. DOI: 10.1080/1059924X.2016.1179612.

Hayati A, Marzban A, Asoodar MA. 2015. Ergonomic assessment of hand cow milking operations in Khuzestan Province of Iran. Agricultural Engineering International: CIGR Journal 17(2): 140145.

Hignett S, McAtamney L. 2000. Reba: rapid entire body assessment. Applied Ergonomics 31(2): 201-205.

Hostiou N, Cialdella N, Vazquez V, Müller AG, Le Gal P-Y. 2015. Work organization on smallholder dairy farms: a process unique to each farm. Tropical Animal Health and Production 47(7):12711278. DOI: $10.1007 / \mathrm{s} 11250-015-0859-7$.

Jakob M, Liebers F, Behrendt S. 2012. The effects of working height and manipulated weights on subjective strain, body posture and muscular activity of milking parlor operatives - Laboratory study. Applied Ergonomics 43(4): 753-761. DOI: $10.1016 / \mathrm{j}$. apergo.2011.11.009.

Kolstrup CL, Hultgren J. 2011. Perceived physical and psychosocial exposure and health symptoms of dairy farm staff and possible associations with dairy cow health. Journal of Agricultural Safety and Health 17(2): 111-125. DOI: 10.13031/2013.36496.

Kolstrup LC, Jakob M. 2016. Epidemiology of musculoskeletal symptoms among milkers and dairy farm characteristics in Sweden and Germany. Journal of Agromedicine 21(1): 43-55. DOI: 10.1080/1059924X.2015.1106373.

Kuorinka I, Jonsson B, Kilbom A, Vinterberg H, Biering-Sorensen F, Andersson G, et al. 1987. Standardised Nordic questionnaires for the analysis of musculoskeletal symptoms. Applied Ergonomics 18 (3): 233-237. DOI: 10.1016/0003-6870(87)90010-X.

Lundqvist P, Stål M, Pinzke S. 1997. Ergonomics of cow milking in Sweden. Journal of Agromedicine 4(1-2): 169-176. DOI: 10.1300/ J096v04n01 21.

Maia LR, Rodrigues LB. 2012. Saúde e segurança no ambiente rural: uma análise das condições de trabalho em um setor de ordenha. Ciência Rural 42(6): 1134-1139.

Milani AP, Souza FA. 2010. Granjas leiteiras na região de Ribeirão Preto - SP. Engenharia Agrícola 30(4): 742-752. DOI: 10.1590/ S0100-69162010000400018.

Németh G, Arborelius UP, Svensson OK, Nisell R. 1990. The load on the low back and hips and muscular activity during machine milking. International Journal of Industrial Ergonomics 5(2): 115 123. DOI: 10.1016/0169-8141(90)90002-J.

Oliveira CC, Merino EAD, Moro ARP, Ulbricht L. 2013. Determination of the lifting index (LI) of NIOSH equacion in milkings manual activity in rural properties in COMCAM region, Brazil. Espacios 34(12).

Oliveira CC, Ulbricht L, Moro ARP. 2017. Avaliação da exposição dos trabalhadores da pecuária leiteira aos riscos ocupacionais. Revista Uniandrade 18(1): 1-15. DOI: 10.18024/1519-5694/ revuniandrade.v18n1p1-15.

Onofri L, Michaloski AO. 2015. Survey of environmental risks in dairy farming in Brazil. Espacios 36(9): 15.

Perkiö-Mäkelä M, Hentilä H. 2005. Physical work strain of dairy farming in loose housing barns. International Journal of Industrial Ergonomics 35(1): 57-65. DOI: 10.1016/j.ergon.2004.08.004.

Pinzke S, Stål M, Hansson GÅ. 2001. Physical workload on upper extremities in various operations during machine milking. Annals of Agricultural and Environmental Medicine 8(1): 63-70.

Pinzke S. 2003. Changes in working conditions and health among dairy farmers in southern Sweden. A 14-year follow-up. Annals of Agriculture and Environmental Medicine 10(2): 185-195.

Soares SO, Oaigen RP, Barbosa JD, Oliveira CMC, Albernaz TT, Domingues FN. 2013. Perfil dos produtores de leite e caracter- 
ização técnica das propriedades leiteiras dos municípios de Rondon do Pará e Abel Figueiredo, Estado do Pará. Veterinária em Foco 10 (2): $159-168$.

Stål M, Moritz U, Gustafsson B, Johnsson B. 1996. Milking is a highrisk job for young females. Scandinavian journal of rehabilitation medicine 28(2), 95-104.

Stål M, Pinzke S, Hansson GÅ. 2003a. The effect on workload by using a support arm in parlour milking. International Journal of Industrial Ergonomics 32(2): 121-132. DOI: 10.1016/S0169-8141 (03)00046-5.
Stål M, Pinzke S, Hansson GA, Kolstrup C. 2003b. Highly repetitive work operations in a modern milking system. A case study of wrist positions and movements in a rotary system. Annals of Agricultural and Environmental Medicine 10(1): 67-72.

Ulbricht L, Romaneli EFR, Stadnik AMW, Maldaner M, Neves EB. 2014. Prevalence of work-related musculoskeletal disorders (WMSD) symptoms among Milkers in the State of Paraná, Brazil. In : Arezes PM, et al., eds. Occupational Safety and Hygiene II. London: CRC Press - Taylor \& Francis Group, pp. $57-61$.

Cite this article as: Caldas de Oliveira C, Augusto de Paula Xavier A, Ulbricht L, Moro ARP, Belinelli MM. 2018. Health in the rural environment: a postural evaluation of milking workers in Brazil. Cah. Agric. 27: 35004. 